\title{
KRZYSZTOF KoŹMIŃSKI
}

Uniwersytet Warszawski

\section{MIĘDZY BIUROKRACJĄ A 'QUANGOKRACJĄ'. KILKA SŁÓW O REFORMIE SŁUŻBY CYWILNEJ ZA CZASÓW MARGARET THATCHER}

\section{Kontrowersje}

Choć od 1990 r., kiedy to Margaret Thatcher składała rezygnację z funkcji premiera rządu Jej Królewskiej Mości, minęło już wiele czasu, działania Partii Konserwatywnej pod jej przywództwem wciąż budzą emocje i niemałe kontrowersje. Wystarczy sięgnąć do przebiegu niedawnej dyskusji, przeprowadzonej na łamach brytyjskiej prasy, a zainicjowanej przez artykuł Jeremy'ego Heywooda oraz Boba Kerslake'a', starszych rangą i wielce zasłużonych członków brytyjskiej civil service ${ }^{2}$. Zauważyli oni, że - choć dużo pisze się o postaci „Żelaznej Damy” w kontekście jej osobistej charyzmy, stylu politycznego przywództwa oraz bezkompromisowego stanowiska wobec związków zawodowych, a także odważnej postawy na arenie międzynarodowej - znacznie mniej miejsca poświęca się wpływowi, jaki wywarła na funkcjonowanie administracji publicznej Jej Królewskiej Mości oraz brytyjski model urzędniczy.

1 J. Heywood, B. Kerslake, Margaret Thatcher: our kindly boss, by Britain's top civil servants, «The Telegraph», z 15 kwietnia 2013 r.

2 Sir Jeremy Heywood pełnił m.in. funkcję Sekretarza Gabinetu (Cabinet Secretary), Sir Bob Kerslake natomiast zajmował stanowisko Head of the Home Civil Service. 
Jest to tym bardziej zaskakujące, że był to wpływ niebagatelny, a wytyczony w latach osiemdziesiątych kierunek zmian stanowi do dnia dzisiejszego ważny punkt orientacyjny w debatach na temat wydajności służb publicznych i udoskonalania zarządzania sferą publiczną. „Gdy doszła do władzy w 1979 r... członkowie służby cywilnej postrzegani byli jako co najwyżej szafarze zarządzający uporządkowanym zmierzchem potęgi Wielkie Brytanii” (all-too-willing stewards of the „orderly decline of Britain”), natomiast jedenaście lat później, gdy opuszczała mieszkanie przy Downing Street nr 10, sytuacja wyglądała już diametralnie różnie, a styl funkcjonowania kadry urzędniczej został znacznie zmodernizowany"3. Zmiany, które miały dokonać się pod wpływem konserwatywnych rządów w latach osiemdziesiątych - w tym zwłaszcza wprowadzenia zasady konkurencyjności, redukcji zatrudnienia o 171 tys. etatów i postawienia na efektywność rozumianą jako wdrażanie najlepszych biznesowych wzorców - komentatorzy nazywają metaforycznie „prawdziwym wstrząsem sejsmicznym” dla administracji na Wyspach. Co więcej, wstrząs ten okazał się być impulsem dla dalszych reform, wcielanych w życie nie tylko przez bezpośredniego następcę Thatcher premiera z Partii Konserwatywnej, Johna Majora, ale i samych labourzystów, którzy wcześniej bardzo nieprzychylnie odnosili się do neoliberalnych projektów lansowanych przez torysowskie rządy.

Heywood i Kerslake nie ograniczyli się do zaakcentowania profesjonalizmu i odwagi przywódczyni torysów w reformowaniu brytyjskiej administracji publicznej, ale podjęli próbę - poprzez sformułowanie szeregu komplementów pod adresem niedawno zmarłego polityka ocieplenia wizerunku rzekomo nieugiętej i zimnej „Żelaznej Damy”. Autorzy artykułu nakreślili jednoznacznie pozytywny obraz pracującego do późnych godzin męża stanu, który - choć wymagał od swych współpracowników najwyższego profesjonalizmu, pełnej koncentracji, dyscypliny i zaangażowania - nie tylko doceniał ich rady i liczył się ze zdaniem innych, a także potrafił częstować ich własnoręcznie upieczonym ciastem pasterskim późną nocą. Trudno dziwić się zatem (a już tym bardziej mając świadomość kontrowersji wokół oceny

\footnotetext{
3 J. Heywood, B. Kerslake, op. cit.
} 
reform lat osiemdziesiątych wśród Brytyjczyków), że artykuł Heywooda i Kerslake’a wywołał sporą burzę. Autorom zarzucono m.in., że - wypowiadając życzliwe słowa wobec Margaret Thatcher (określone przez krytyków mianem „hagiografii”) i formułując przychylne oceny reform administracji z lat osiemdziesiątych (zdaniem krytyków wyjątkowo jednostronne) - nie tylko wykazali się lizusostwem względem obozu partyjnego dawnej premier, ale i naruszyli szereg zasad służby cywilnej: neutralności, bezstronności światopoglądowej, a nawet niedopuszczalnym zaangażowaniem politycznym w stopniu, który nie przystoi najwyższym urzędnikom civil service. Pojawiły się nawet brutalne zarzuty o „prostytuowanie” profesji urzędniczej.

W końcu sformułowano oskarżenie, jakoby najwyższym przedstawicielom służby nie wypadało chwalić polityka, za którego kadencji jej kadry zmniejszyły się aż o 171 tys. stanowisk (badacze podają, że ogółem w latach 1979-1995 ilość członków służby cywilnej spadła z liczby 732 tys. do 524 tys. $\left.{ }^{5}\right)$, co stanowi ewidentny dowód jej osłabienia. Kierunek reform lat osiemdziesiątych oraz ogólny bilans rząaów torysów pod przywództwem Thatcher mają prowadzić do wniosku, że - zwłaszcza zdaniem labourzystów - nietaktowne jest portretowanie przywódczyni konserwatystów w tak lukrowany sposób, a czułe obrazy baronessy Thatcher częstującej urzędników civil service ciastem pozostają niekoniecznie, zwłaszcza w kontekście owych tysięcy urzędników skazanych na bezrobocie, zgodne z rzeczywistością.

Wspomniana wyżej dyskusja symbolizuje żywe do dnia dzisiejszego kontrowersje związane z oceną brytyjskiej premier i bilansu promowanych w jej czasach reform. Wystarczy rzut oka na ty tuły prasowe z $2013 \mathrm{r}$. (data śmierci Margaret Thatcher), by przekonać się, że na dorobek liderki konserwatystów - obok niekwestionowanych osiągnięć (jakimi z pewnością były wojna o Falklandy, ograniczenie roli związków zawodowych, prywatyzacja nierentownych gałęzi gospodarki) - składały się również

4 R. Syal, Pro-Margaret Thatcher article by two senior civil servants angers MPs, «The Guardian»z 18 kwietnia 2013 r.; O. WRIGHT, MPs attack top civil servants over Thatcher tribute, «The Independent» $\mathrm{z} 18$ kwietnia $2013 \mathrm{r}$.

5 T. Butcher, The Civil Service in the 1990s: The Revolution Rolls On, «Talking Politics» 3/1995, s. 39. 
i takie decyzje, których ocena nie jest wcale jednoznaczna (m.in. reformy administracji lokalnej, które doprowadzić miały w efekcie do kryzysu samorządu terytorialnego, partycypacji społecznej i demokracji lokalnej ${ }^{6}$ czy zastąpienie podatku gminnego instytucją daniny publicznoprawnej "poll tax", przypominającej podatek pogłówny ${ }^{7}$ ).

Wydaje się, że zachwalane przez Heywooda i Kerslake's zmiany w administracji publicznej, w tym zwłaszcza nowatorskie podejście do civil service, należą do tej drugiej grupy - mogą być i są przedmiotem sporów. Chwalone przez jednych reformy spotykają się zarazem z krytyczną oceną grupy komentatorów, którzy czas rządów konserwatystów nazywają okresem upolitycznienia kadry urzędniczej ${ }^{8}$ oraz upatrują w nich źródła upadku etosu służby publicznej ${ }^{9}$. Niewątpliwie jednak miały one doniosłe znaczenie, trudno nie zgodzić się ze stwierdzeniem, że rządy konserwatystów pod przywództwem „Żelaznej Damy” przyniosły

6 Polskie autorki konstatują, że Thatcher „ze szczególna odrazą odnosiła się do samorządu lokalnego” (B. Toszek, E. Kużelewska, Od wizji do rzeczywistości. Dziesięć lat dewolucji w Walii, Warszawa 2011, s. 62), a Lucyna Rajca tłumaczy, że „to właśnie te elementy rewolucji „thatcherowskiej” przekształciły Anglię z państwa historycznie „unitarnego, wysoce zdecentralizowanego” (unitary, highly decentralised) w państwo „unitarne, wysoce scentralizowane” (unitary, highly centralised), zmierzające w odwrotnym kierunku niż reszta Europy. Podczas gdy większość państw Europy Zachodniej przeprowadzała znaczącą decentralizację, Wielka Brytania podążała w przeciwnym kierunku, prowadzącym do poziomu kontroli centralnej, niespotykanej poza Europą Wschodnią (gdzie samorządy lokalne zostały zlikwidowane). Zadania przekazano do niewybieralnych ciał, kontrole finansowe były rozszerzane, a wydatki i stawki podatkowe ustalane przez centrum. W wyniku tego status zarządu lokalnego jako formy samorządu lokalnego obniżał się w latach 80. i 90. ubiegłego stulecia”. L. RAJCA, Reformy samorządu lokalnego w Anglii, «Samorząd terytorialny» 12/2007, s. 59.

W konsekwencji „W Wielkiej Brytanii w latach dziewięćdziesiątych wielu obserwatorów politycznych i naukowców dostrzegało kryzys samorządu lokalnego”. L. RAJCA, Przywództwo polityczne w zachodnioeuropejski samorządzie lokalnym, «Studia Regionalne i Lokalne»34.4/2008, s. 85.

7 P. Smith, Lessons from the British Poll Tax Disaster, «National Tax Journal», 4 /1991, s. 421-36.

8 D. DŁugosz, Kadry w administracji publicznej, [w:] Administracja publiczna, red. J. HAusner, Warszawa 2005, s. 241.

9 J. Gray, Partia Pracy $i$ mity thatcheryzmu, «Dziennik» z 5 listopada 2007 r., s. 34 . 
poważne zmiany w funkcjonowaniu brytyjskiej civil service, a sama „Pani Thatcher miała większy wpływ na funkcjonowanie służby cywilną niż każdy dotychczasowy minister lub premier" ${ }^{10}$.

Celem niniejszego artykułu jest zatem rzucenie światła na zmiany w działaniu wybranych instytucji brytyjskiej administracji publicznej za czasów rządów konserwatystów pod wodzą Margaret Thatcher. Pomijając już sam spór o ocenę zasadności redukcji etatów civil service, lata osiemdziesiąte to okres, w którym w debacie publicznej szczególną popularnością cieszą się hasła o potrzebie „walki z biurokracją”, „odchudzenia państwa” oraz „cięć wydatków publicznych”. Późniejsi komentatorzy scharakteryzują go jako czas tryumfu neoliberalnej idei „nowego zarządzania publicznego" (New Public Management) oraz transformacji modelu kadr urzędniczych od „biurokracji w starym typie” do „nowej biurokracji”"11. Uwagi niniejsze dotyczą jedynie kilku wybranych kwestii i nie mogą aspirować do miana wyczerpującego omówienia zagadnienia określonego tytułem, stanowić mogą jednak wstęp do bardziej pogłębionej analizy problemu.

Tak zakreślony temat jest zarazem doskonałą okazją do zaprezentowania kilku konkretnych rozwiązań wpisujących się w praktykę nowego zarządzania publicznego. Zaryzykować można bowiem tezę, że - choć problematyka NPM oraz governance jest w polskiej literaturze coraz lepiej znana i wciąż analizowana - nie sposób nie odnieść wrażenia, że relacjonujący ją autorzy koncentrują się na ogół na referowaniu ideologicznych założeń postulowanych rozwiązań i docelowej wizji administracji promowanej przez jej zwolenników, natomiast rzadko kiedy ilustrują konkretne przykłady wprowadzonych na fali NPM reform instytucjonalnych ${ }^{12}$. Innymi słowy, szereg krajowych publikacji sze-

\footnotetext{
10 C. Pilikington, The Civil Service in Britain Today, New York 1999, s. 67.

11 D.J. Savoie, Thatcher, Reagan, and Mulroney: In Search of a New Bureaucracy, University of Pittsburgh Press, Pittsburg 1994.

12 Przykładowo Nowe zarzadzanie publiczne i public governance $w$ Polsce i $w$ Europie, red. H. Izdebski, A. Bosiacki, A. Nelicki, I. Zachariasz, Warszawa 2010; J. Supernat, Administracja publiczna w świetle koncepcji New Public Management, [w:] Jednostka, państwo, administracja - nowy wymiar, red. E. URA, Rzeszów 2004, s. 469490; A. ZALEWsKi, Nowe zarządzanie publiczne w polskim samorządzie terytorialnym,
} 
roko (z uwzględnieniem historycznego tła, aksjologii, teoretycznych dywagacji) omawia kluczowe dla NPM hasła (takie jak „deregulacja, debiurokratyzacja, decentralizacja, ekonomizacja działań oraz zorientowanie na efekty... wzmacnianie responsywności urzędników oraz szerokie wykorzystanie technologii informatycznych do świadczenia usług publicznych”13, „prywatyzacja”, „marketyzacja stosunków wewnątrz sektora publicznego"14, „konsumeryzm”"15, a często odwołując się do modnych haseł bez ich spolszczenia: „accountability”, „efficiency”, "participation”, "flexibility”, „deregulation”, „outsourcing”), sporadycznie obrazując zrealizowane w tym duchu projekty w Wielkiej Brytanii, Stanach Zjednoczonych, Kanadzie czy Nowej Zelandii.

W pierwszej kolejności zaprezentowana zostanie (w zarysie) opinia konserwatystów na temat dotychczasowego modelu służby cywilnej, z uwzględnieniem jej hierarchicznej i jednorodnej struktury oraz włączenia w „tradycyjny”, nieefektywny system departamentów, a także niejednoznaczny stosunek względem instytucji quangos. Następnie przedstawione zostaną wybrane reformy przeprowadzone przy dużym zaangażowaniu najbliższych współpracowników Thatcher - szczególnie

Warszawa 2005; B. Kożuch, Zarządzanie publiczne. W teorii i praktyce polskich organizacji, Warszawa 2004; J. Hausner, Od idealnej biurokracji do zarzadzania publicznego, [w:] Studia z zakresu zarządzania publicznego, II, red. J. Hausner, M. KukieŁKA, Kraków 2002, s. 62-64; P. JEżowsKi [red.], Zarządzanie w sektorze publicznym - rozwój zrównoważony - metody wyceny, Warszawa 2002. Warto w tym kontekście zwrócić uwagę na publikację Michała Kuleszy i Dawida Sześciło „Polityka administracyjna i zarządzanie publiczne”, której autorzy nie tylko omawiają podejścia do administracji publicznej (model weberowski, nowe zarządzanie publiczne, koncepcje governance oraz neo-weberowskie), ale prezentują także - poprzez zamieszczenie w książce przykładowych, przetłumaczonych na język polski dokumentów - realny wymiar reform instytucjonalnych. M. Kulesza, D. SześcıŁo, Polityka administracyjna i zarządzanie publiczne, Warszawa 2013.

13 B. JaWOrsKa-DęBSKa, Etos służby publicznej i jego oblicza, [w:] Służba publiczna. Stan obecny, wyzwania i oczekiwania, red. S. PŁAżeK, M. STEC, «Lex» 2013.

14 G. Musialik, R. Musialik, Związek sektora publicznego i rynkowego w koncepcji New Public Management, «Studia Ekonomiczne. Zeszyty Naukowe Uniwersytetu Ekonomicznego w Katowicach» 156/2013, s. 293.

15 D. Stewart-David, M. ŚLIwA, Jak efektywnie wykorzystać czas pracowników?, [w:] Rozwój kadr w administracji publicznej, red. B. KuDRYCKA, Białystok 2001, s. 187. 
Dereka Raynera oraz Robina Ibbsa - których efektem miało być (rzekome) „odchudzenie państwa” oraz kampania (w dużym stopniu czysto wizerunkowa) „podpalenia quangos”, przy jednoczesnym wcielaniu w życie planu „Następnych Kroków” (Next Steps), czego skutkiem była realizacja idei „dezagregacji” administracji publicznej poprzez powołanie licznych agencji wykonawczych. Reformy te, jak zostanie wykazane, poza umiarkowanym sukcesem propagandowym, nie przyczyniły się wcale do realizacji postulatów odbiurokratyzowania „chudego państwa” (lean state), ani też redukcji liczby quangos (spowodowały nawet, wobec petryfikacji wielu dotychczas istniejących oraz utworzenia nowych agencji wykonawczych, wzrost ich faktycznej ilości), lecz ich przeprowadzenie miało niebagatelne znaczenie dla organizacji i funkcjonowania civil service.

\section{KRYTYKA BIUROKRACJI, QUANGOKRACJI ORAZ PATRONAŻU}

Koncepcje nowego zarządzania publicznego - choć obejmowały najróżniejsze, niekoniecznie koherentne, idee i promowane rozwiązania - bazowały przede wszystkim na krytyce tradycyjnego, postrzeganego jako „przestarzały” modelu administracji publicznej ${ }^{16}$. Zastrzeżenia względem struktury biurokratycznej rozbudowanego państwa dobrobytu oraz wiązanie jego nieefektywności z symptomami kryzysu gospodarczego nie dotyczyły zresztą tylko administracji centralnej, lecz także lokalnej: punktowano niską jakość świadczeń komunalnych, niedostosowanie ich do rzeczywistych potrzeb obywateli oraz mało efektywne gospodarowanie zasobami przez władze samorządowe ${ }^{17}$. W środowisku angielskich konserwatystów samorząd terytorialny postrzegano jako skostniały, rozrzutny, marnotrawiący środki i, w konsekwencji, nieefektywny w dostarczaniu usług publicznych.

16 G. Kozuń-Cieślak, Teoretyczne koncepcje decentralizacji i delegowania kompetencji we współczesnych nurtach ekonomii, "Samorząd terytorialny» 9/2011, s. 28.

17 K. RADZIK, Od Thatcher do Browna: polityka rządów brytyjskich wobec samorządu terytorialnego (1979-2010), «Zarządzanie Publiczne»13.1/2011, s. 38. 
„New Public Management funkcjonuje bowiem w symbiozie z neoliberalną wizją państwa i gospodarki, przenosi na grunt myślenia o administracji publicznej podstawowe dyrektywy neoliberalizmu ${ }^{18 "}$. Wybitni politycy anglosascy owego okresu: Margaret Thatcher, Ronald Reagan oraz premier Kanady Brian Mulroney obejmowali urzędy przekonani nie tylko o przeroście zakresu zadań państwa opiekuńczego, ale także współodpowiedzialności dotychczasowego modelu biurokracji za stagnację gospodarki. Przywódcy ci byli nie tylko antyetatystyczni (antigovernment), ale przede wszystkim anty-biurokratyczni (antibureucracy) dlatego więc - obok potrzeby reorganizacji ustrojowej - dostrzegali konieczność reformy podległej im służby cywilnej ${ }^{19}$. Krytyka administracji skonstruowanej na podstawie tradycyjnego modelu weberowskiego łączyła się z atmosferą nieufności względem najróżniejszych instytucji włączonych w proces wykonywania zadań publicznych, tym bardziej jeśli dysponowały one środkami publicznymi oraz, mimo znacznego zakresu samodzielności (a może tym bardziej, że były one samodzielne), zostały zaangażowane w proces decyzyjny, tj. wykonywały władztwo regulacyjne albo realizowały zadania z zakresu administracji świadczącej. Postawę taką doskonale obrazuje komentarz Thatcher na pytanie o zasadność utrzymywania Rady ds. Sztuki (Arts Council): „Nie byłam przekonana, czy rolą państwa jest pełnienie zadań mecenasa sztuki. Talent artystyczny - a co dopiero geniusz sztuki - jest nieplanowany, nieprzewidywalny, ekscentrycznie indywidualny. Poddany dyscyplinie, dofinansowany, zarządzany przez państwo i należący do państwa, usycha. Co więcej, państwo w takiej sytuacji staje się instrumentem w rękach artystycznego lobby. Chciałam doprowadzić do sytuacji, w której to prywatny sektor przynosi pieniądze, a także uczy instytucje kultury biznesowej orientacji oraz efektywności" ${ }^{20}$. A Rada ds. Sztuki była tylko jedną z wielu spośród grupy liczącej kilkaset podmiotów quangos.

Czym są quangos? Nawet dość pobieżny przegląd literatury przedmiotu pozwala zorientować się, że termin ten - choć spopularyzowany

18 M. Kulesza, D. SześciŁo, op. cit., s. 59.

19 D.J. SAvoie, op. cit., s. IX.

20 O. Turnbull, Bringing Down the House: The Crisis in Britain's Regional Theatres, Bristol 2008, s. 73. 
jeszcze na początku lat osiemdziesiątych poprzedniego stulecia ${ }^{21}$ - jest wciąż wielce problematyczny. Brak zgodności co do jednolitej definicji quango (nieraz w krótszym wydaniu „qango”), a ich ilość, rodzaje, rozmaitość pełnionych funkcji oraz różnorodność statusu prawnego powoduje, że autorzy ograniczają się na ogół do najbardziej rozpowszechnionej, generalnej i intuicyjnej definicji „quasi-autonomicznych organizacji pozarządowych” lub też „quasi-niezależnych organizacji pozarządowych"22 (quasi-autonomous non governmental organisations). Co więcej, na trudność w wypracowaniu spójnego znaczenia mają wpływ odmienne tradycje, lokalne rozwiązania i specyfika narodowych modeli administracji publicznej. Definicyjny problem polega m.in. na tym, że liczba i rozmaitość podmiotów, które charakteryzuje się jako quango jest tak wielka, że stawia to pytanie o możliwość wypracowania jednej spójnej interpretacji, która byłaby prawidłowa dla wszystkich tych jednostek różnie zorganizowanych i funkcjonujących w odmienny sposób w Wielkiej Brytanii, Holandii, Danii, USA itd. Trudno wyobrazić sobie zatem stworzenie jednej, powszechnie akceptowanej, a tym bardziej „międzynarodowej” definicji, która znajdowałaby zastosowanie dla wszelkich podmiotów, będących w wielu krajach charakteryzowanymi jako quango ${ }^{23}$. Przykładowo tylko: Stanisław Mazur charakteryzuje je jako „swoistego rodzaju agencje prywatne, działające w imieniu państwa” ${ }^{24}$, inni autorzy jako „operacyjne agencje quasi-rządowe”25. Zamiast definiować, próbuje się wskazywać ich cechy. I tak podkreśla się często, że quangos funkcjonują w „szarej strefie” („grey-zone”),

${ }^{21}$ Za twórcę i popularyzatora terminu „quango” uchodzi Anthony Barker, który zaprezentował ów termin w publikacji z 1982 r. „Quangos in Britain: Government and the Networks of Public Policy-making".

22 Tak np. H. Izdebsкi, M. Kulesza, Administracja publiczna. Zagadnienia ogólne, Warszawa 2004, s. 172.

23 C. Greve, M. Flinders, S. van Thiel, Quangos - What's in a name? Defining Quangos from a Comparative Perspective, «Governance» 12.2/1999, s. 130.

24 S. Mazur, Historia administracji publicznej, [w:] Administracja publiczna, red. J. HAusner, Warszawa 2005, s. 58.

25 B. Ledzion, K. Olejniczak, W. PANder, Ewaluacja trafności zakresu interwencji Działania 5.1 Programu Operacyjnego Kapitał Ludzki, www.efs.kprm.gov.pl, Warszawa s. 17 . 
tj. przestrzeni pomiędzy sferą publiczną oraz prywatną ${ }^{26}$. Pod pojemnym pojęciem quango rozumie się szereg podmiotów, które działać mogą zarówno lokalnie, jak i na poziomie ogólnokrajowym. Funkcjonują w najróżniejszych sferach życia: od nauki i edukacji, poprzez sport, sztukę, politykę ekologiczną, kontrolę jakości produktów, aż po ochronę zdrowia. Ich rolą może być doradzanie (funkcja opiniodawcza), funkcja orzecznicza, sprawowanie władztwa regulacyjnego, udział w procesie stanowienia prawa, koordynowanie debat i udział w wypracowywaniu polityk publicznych, działania promocyjne.

Mówiąc o kontekście brytyjskim: „w Wielkiej Brytanii termin "quango" zdaje się być stosowany do określenia wszystkiego... najbliższe prawdzie byłoby uznanie po prostu, że każda organizacja niemająca jednoznacznie prywatnego czy publicznego charakteru może być uznana za quango" ${ }^{27}$. Do grupy tej zalicza się m.in. ciała o statusie NDPB (non-departmental public body), niezależne agencje regulacyjne typu IRA (independent regulatory agency), organizacje pozarządowe typu EGO's (extra-governmental organizations) czy NGO (non-governmental organization), QAO (quasi-autonomous organizations) i SAO (semi-autonomous organization $)^{28}$. Nie może dziwić zatem konstatacja: „NDPBs, EGOs, NGOs, QAOs... lista terminów kojarzonych z modelem organizacji, które - pełniąc funkcję publiczną - wydają publiczne pieniądze, lecz funkcjonują w pewnym stopniu niezależnie od wybieranych polityków, jest nieskończenie długa"29.

Choć tradycja powoływania ciał i instytucji, których rolą było wykonywanie zadań należących tradycyjnie do administracji rządowej, jest w Anglii długa i sięgać ma nawet XVII w. (przykładem ciała, które - ze względu na pełnioną funkcję - już w odległej przeszłości cieszyło się sporą niezależnością od powołującej je władzy centralnej, może być

26 G. Peters, J. Pierre, The Sage Handbook of Public Administration, London 2012, s. 237.

27 C. Greve, M. Flinders, S. van Thiel, op. cit., s. 136.

28 I. Deviatnikovaité, A. Bakaveckas, Independent Regulatory Agencies: Possibilities to Identify the Pecularities of their Activity and their Position in the System of Lithuanian Public Administration Bodies, «Socialinių mokslų studijos» 3/2009, s. 333.

29 C. Greve, M. Flinders, S. van Thiel, op. cit., s. 130. 
np. Board of Trade $e^{30}$, znane były już wówczas przypadki powierzania określonych zadań o charakterze publicznoprawnym organizacjom dobroczynnym; wiele utworzonych zostało w okresie powojennym, jak np. wspomniana wyżej The Arts Council of Great Britain w 1946 r., której pierwszym prezesem został - co zupełnie przypadkowe, choć wielce wymowne - John Maynard Keynes), to właśnie za czasów rządów torysów w latach osiemdziesiątych oraz początku dziewięćdziesiątych, a także kontynuacji procesu przez rządy labourzystowskie, odnotować można zjawisko „eksplozji quangos” - prowadzące w konsekwencji do stanu, w którym jeszcze niedawno funkcjonowało około 800 podmiotów, kwalifikowanych jako quangos w szerokim znaczeniu ${ }^{31}$.

Zaobserwować można zatem pewien paradoks: choć podmioty te włączone były w proces szeroko rozumianego administrowania, a praktykę ową stanowczo krytykowali politycy angielskiej prawicy w latach siedemdziesiątych i osiemdziesiątych, ich rządy nie tylko nie przyczyniły się do redukcji liczby quangos oraz ograniczenia ich roli w życiu gospodarczym, społecznym, kulturalnym oraz sportowym kraju, ale - po przejęciu władzy - przyczynili się do postępów procesu „quangokratyzacji” Królestwa. Rezultatem tego stanu rzeczy był oficjalny dokument rządowy, pokłosie przeprowadzonego przeglądu quangos (który prowadzony był - jak obrazowo relacjonowały media brytyjskie - w atmosferze „spalenia quangos”: „,bonfire of the quangos”,32, wprost nawiązując do powieści Toma Wolfe'a pt. "The Bonfire of the Vanities" oraz (sic!) radykalnych działań prowadzonych przez Savonarolę w piętnastowiecznej Florencji, której mieszkańcy publicznie i masowo niszczyli wszelkie „symbole grzechu” i „źródła próżności”: kosmetyki, przedmioty sztuki, kosztowności itp. $\left.{ }^{33}\right)$, datowany na dzień

30 A.M. KJAER, Governance ant the Urban Bureaucracy, [w:] Theories of Urban Politics, red. J. S. Davies, D. Imbroscio,London 2009, s. 146.

31 H. LeE, Regaining Political Control Over the British Quango State: The Public Bodies Reform, "Journal of Public Policy» 1/2014.

32 J. Parkinson, Politicians' love/hate relationship with quangos, «BBC News Website» Z 14 października $2010 \mathrm{r}$.

33 A. Gaвbатt, Quango lingo: Bonfire of the vanities, and other inanities, "The Guardian» z 15 października $2010 \mathrm{r}$. 
14 października 2010 r. pt. „Public Bodies Reform - Proposals for Change”, w którego treści postulowano: zachować około połowy dotychczas istniejących quangos $\mathrm{w}$ stanie niezmienionym, znaczną ilość podmiotów zlikwidować (w liczbie 192), niektóre scalić (118), a pozostałe istotnie zreformować (171).

Pora tu na dokonanie spostrzeżenia ogólniejszej natury: z jednej strony, tworzenie quangos - z założenia niepodlegających bezpośrednio centralnej administracji rządowej i wyspecjalizowanych w wykonywaniu wąsko określonych zadań - wpisuje się w logikę nowego zarządzania publicznego. Ich niekwestionowaną zaletą jest elastyczność (flexibility), tj. możliwość szybkiego utworzenia i zmodyfikowania, bez konieczności podejmowania długotrwałych i skomplikowanych procedur demokratycznych, a także „rozliczalność” (accountability), czyli przydzielenie ograniczonych środków finansowych, których wydatkowanie jest konsekwentnie monitorowane. Co więcej, wykorzystanie quangos "odciąża” administrację rządową (która - poprzez zawarcie swoistego kontraktu publicznoprawnego, którego treścią było zlecenie wykonywania określonych zadań w zamian za finansowanie - zwolniona zostaje z wykonywania określonych zadań publicznych, sprawując za to tylko ograniczony nadzór nad realizacją powierzonych zadań przez konkretne quango).

$\mathrm{Z}$ drugiej jednak strony, funkcjonowanie takich podmiotów (zwłaszcza w przypadku wyposażenia ich w kompetencje o charakterze władczym) musi rodzi pytania o ich legitymizację, możliwość sprawowania demokratycznej kontroli, a przez to ich faktyczne „oddalenie” od obywateli. Mówiąc bardziej obrazowo: quangos sprawiają wrażenie bezdusznego, nieczułego na emocje społeczne i sytuację polityczną, technokratycznego aparatu. Co więcej, sama już nazwa "quango" sugeruje, że istotą działania tych podmiotów jest ich autonomiczność, względna niezależność od centrum rządu, a w konsekwencji rozdzielenie od bieżącej polityki. Doświadczenie uczy jednak, że w praktyce podlegają one jednak wpływom politycznym ${ }^{34}$. Ponadto, fakt ich tworzenia i powierzania kompetencji nie świadczy wcale o redukcji obciążeń

${ }^{34}$ H. LEE, op. cit. 
administracyjnych - zmienia się jedynie podmiot, na który nałożono obowiązek realizacji określonych zadań: wcześniej była nim administracja rządowa, które później przejmuje podmiot wchodzący w skład struktury owej quasi-administracji.

Znajduje tu zatem zastosowanie zasada, że o ile quangos stanowią wdzięczny przedmiot ataku dla polityków będących aktualnie w opozycji (i dotyczy to zarówno konserwatystów, jak i labourzystów), którzy podnoszą zarzuty ich przerostu biurokratycznego, nieefektywności działania oraz niedemokratycznego sposobu wyłaniania kierownictwa - przejmujący władzę politycy „zakochują się” w nich i bronią, niezależnie od wcześniejszych deklaracji ${ }^{35}$. Zdarzało się wielokrotnie, że dany podmiot był likwidowany, by krótko później zmartwychwstać pod nową nazwą i w nieco tylko zmienionej formie organizacyjnej (np. Physical Training and Recreation Council powróciła jako Sports Council; podobny los spotkał wyśmiewaną za czasów rządów Thatcher Eggs Authority - podmiot, którego działania koncentrowały się na reklamie i promowaniu wiedzy o krajowym rynku jaj, o budżecie szacowanym na ok. 3 miliony funtów, na co składały się głównie opłaty uiszczane przez producentów; podmiot został zniesiony w 1986 r., lecz przywrócony krótko potem jako British Egg Industry Council) ${ }^{36}$. Bywało także, że choć w danym okresie nominalnie ilość quangos spadała z powodu redukcji zarządzonych przez polityków rządzącej partii (choć, jak wspomniano, wobec niejednoznaczności pojęcia quango każda próba wyliczenia ich liczby budzi kontrowersje, a plany redukcji dają szerokie pole manipulacji - ponieważ to właśnie od przyjętej definicji pojęcia quango zależy udzielenie odpowiedzi o skalę reformy: szersza definicja pozwala postawić tezę, że jest ich znacznie więcej niż w rzeczywistości, podczas gdy definicja wąska pozwala ograniczyć się do określonego rodzaju quango, np. tylko NDPBs), wydatki budżetowe przeznaczane na finansowanie istniejących były faktycznie jeszcze wyższe niż przed procesem redukcji. Finalnie zatem nie budzi kontrowersji teza, że opinie

35 T. Sтотт, Quangos: are they unloved and misunderstood?, [w:] Debates in British Politics Today, red. L.J. Robins, B. Jones, Manchester 2000, s. 89.

36 C. Greve, M. Flinders, S. van Thiel, op. cit., s. 135. 
o oszczędnościach finansowych, które przynosić miało przekazywanie władzy do quangos przez administrację rządową, są przesadzone ${ }^{37}$.

Mając zatem świadomość faktu, że quangos miały już na Wyspach (i to na wiele lat przed objęciem rządu przez Margaret Thatcher) długą tradycję, a zachowanie polityków obu wielkich partyjnych obozów było względem nich niejednoznaczne, warto podjąć próbę udzielenia odpowiedzi na pytanie o faktyczny stosunek „Żelaznej Damy” do quangokracji. Była ich przeciwnikiem, czy też postrzegała je jako instrument niezbędny do przekształcenia państwa opiekuńczego w „chude państwa” (lean state)? Czy w latach osiemdziesiątych brytyjskie quangos wzmocniły swoją pozycję, czy też może ich rola w życiu publicznym uległa osłabieniu?

Zapowiedzi były dość jednoznaczne... Jak relacjonował jeden z komentatorów w 1981 r. w artykule o wymownym tytule: „Mrs. Thatcher stalks the quango: a note on Patronage and Justice in Britain”: „Z godną podziwu konsekwencją i nie zawsze z poparciem członków własnego gabinetu, ona rzeczywiście próbuje ograniczyć zakres działania sektora publicznego. Przykładowo: służba cywilna została już okrojona z liczby 743 tys. etatów do 700 tys., a kolejna obniżka do liczby 640 tys. nastąpi już w przyszłym roku... Generalnie rzecz biorąc, ogół wydatków publicznych zostanie obniżony o ok. 5 procent w ciągu najbliższych czterech lat... Wśród planowanych reform znajduje się m.in. próba cięć wymierzonych w quasi-publiczne agencje, które charakteryzowane są jako quangos. Wśród nich są i takie, jak np. Komisja Fuzji i Monopoli (Mergers and Monopolies Commission), która wydaje 90 tys. funtów rocznie, zatrudnia 27 opłacanych urzędników oraz takie - jak np. Komisja Muru Hadriana (Hadrian's Wall Liaison Commission) - która nie zatrudnia pracowników, a jedynie angażują siedmiu wolontariuszy i nie podlegają kontroli parlamentarnej... Pod przywództwem Phillipa Hollanda, konserwatywnego członka Izby Gmin, oraz w sojuszu z liberalnym Instytutem Adama Smitha, rząd rozpoczął kampanię

37 Tak np.: D.G. Mayes, Z. Mustaffa, The rise of unelected. The UK health system and the rise and fall of arm's length bodies, [w:] The Changing Welfare State in Europe: The Implications for Democracy, red. D.G. Mayes, A. Michalski, Cheltenham 2013, s. 183. 
przeciw quango... rekomendowano zniesienie 50 ciał wykonawczych, 211 doradczych komitetów oraz 5 trybunałów orzeczniczych... bliskie było przekonanie, że quango „nie tylko sprzyjają rozprzestrzenianiu się praktyki patronażu, ale i powodują ukryty rozrost rządu, który nie znajduje odzwierciedlenia w liczbie etatów służby cywilnej... Pan Holland szacuje, że roczny koszt quangos jest zbliżony do sumy, jakie przeznacza się na obronę, czyli około 8 miliardów funtów. Debata w Izbie Lordów ujawniła natomiast, że dzięki istnieniu quango ministrowie dysponują liczbą 5600 płatnych posad do zaoferowania klientom partyjnym... W liście do Phillipa Hollande’a, narodowego łowczego quango, wyraziła pełne poparcie dla poglądu, zgodnie z którym służba cywilna nie powinna zrzekać się swych obowiązków i zadań na rzecz pozarządowych organizacji” 38 . Pewną rolę odgrywał również argument ideologiczny poparcie wolnorynkowych think-tankó $w^{39}$ oraz argumenty dostarczane przez wypowiedzi Friedricha Augusta von Hayeka: „Była jeszcze jedna przyczyna, z powodu której Lady Thatcher nie lubiła quangos. W latach 1978/9 wydały one ponad 14 milionów funtów publicznych pieniędzy i to w sposób niekontrolowany, niedostatecznie monitorowany. System ten obsługiwany był przez pracowników w liczbie przekraczającej milion osób" ${ }^{\prime 4}$.

Podkreślić trzeba, że instytucja quango kojarzona była silnie ze zjawiskiem (występującym i zwalczanym zresztą nie tylko w tradycji brytyjskiej, ale i innych państwach anglosaskich), kojarzonym słusznie z korupcją polityczną, patronażu. „Od połowy lat siedemdziesiątych quangos oraz praktyka patronażu przy obsadzaniu stanowisk stała się centralnym problemem w debatach na temat demokratycznej odpowiedzialności i rozliczalności (accountability). Spore zainteresowanie tymi problemami zdradzają same tytuły prasowe z tego okresu, np. «Eksplozja patronażu» (The patronage explosion), «Nowy system patronażu rozrzuca przywileje jak wystrzał confetti» (How the new system of patronage in

38 R. Presthus, Mrs. Thatcher stalks the quango: a note on Patronage and Justice in Britain, «Public Administration Review»3/1981, s. 313.

39 P. Holland, Quango, Quango, Quango: the Full Dossier on Patronage in Britain, London 1979.

40 Saving the quango, "Third Way» 2/1993, s. 11. 
government scatters the confetti of privilege), czy «Quango - sposób na łatwy zysk» (Quango, the name for Whitehall's latest gravy train)"41. Poza patronażem, nepotyzmem i korupcją, podkreśla się, że specjalizacja quangos sprzyjała niepożądanemu lobbingowi: były one skupione na eksponowaniu wąskich problemów, a w konsekwencji akcentowaniu interesu partykularnego (zgodnego z wizją beneficjentów konkretnej sfery, usługobiorców i usługodawców danych usług), nie zaś interesu generalnego, publicznego ${ }^{42}$.

Mimo twardego stanowiska i buńczucznych zapowiedzi, efekty polityki konserwatystów wobec quangos niekoniecznie odpowiadały obietnicom radykalnych „cięć administracji”: redukcji etatów i osłabienia quangos. O ile jednym z głównych filarów, na których konserwatyści opierali swój program wyborczy była „dogmatyczna kampania przeciw quangos", o tyle - po w wyborach - okazało się, że był to raczej atrakcyjny chwyt retoryczny, a wyrazem tego był m.in. fakt, że kolejne raporty sporządzane dla premier Thatcher łagodziły wcześniejsze radykalne zapowiedzi i podkreślano raczej konieczność reformy niż eliminacji ${ }^{43}$. Co więcej, retoryka polityczna w dyskusjach nad reformą tych organizacji nie wyczerpała się wraz z końcem kampanii wyborczej. Późniejsze „sukcesy” w redukcjach liczby organizacji oparte były na następującej manipulacji: autorzy raportów rządowych tak wąsko definiowali pojęcie quango, że powstawało wrażenie realnej ich redukcji. Gdyby natomiast zastosować inną metodologię (zgodną z brytyjskim, bardzo pojemnym rozumieniem tego terminu), okazałoby się, że cięcia miały charakter kosmetyczny. Same liczby są tu mylące - nawet w przypadku przyjęcia, że ilość quangos w latach osiemdziesiątych ulegała zmniejszeniu, konsekwentnie rosły wydatki budżetowe przeznaczane na ich działanie ${ }^{44}$.

${ }^{41}$ N. Rao, Reviving Local Democracy: New Labour, New Politics?, Bristol 2000, s. 61 .

42 L. Verhey, T. Zwart, Agencies in European and Comparative Perspective, Antwerp-Oxford-New York 2003, s. 30.

43 M. Flinders, K. Dommett, K. Tonkiss, Bonfires and Barbecues: Coalition Governance and the Politics of Quango Reform, "Contemporary British History" 28/2014, s. 64 .

44 Ibidem, s. 64. 
W literaturze podkreśla się, że w rzeczywistości za czasów Żelaznej Damy quangos nadal świetnie prosperowały, a niektóre wręcz roz$k_{\text {kwitały }}{ }^{45}$. Co więcej, ich ilość oraz koszty związane z obsługą funkcjonowania wzrosły ${ }^{46}$. W praktyce zatem okazało się, że instrument, który w założeniu służyć miał „odbiurokratyzowaniu” administracji i „odchudzeniu” państwa stał się jednym z elementów postępującej etatyzacji. Co więcej, formułowane są poglądy, jakoby model państwa opiekuńczego (welfare state) przekształcił się w model państwa-quango (quango-state; quangoland), a dominującym modelem ustrojowym stała się quangokracja (quangocracy). Innymi słowy, niezależnie od popularnego wizerunku Margaret Thatcher jako nieugiętej zwolenniczki cięć wydatków publicznych, także i jej rządy wpisywały się w tendencję, którą w sposób następujący charakteryzują komentatorzy: „Inicjowanie procesu «palenia quangos» jest częścią stale powtarzanej politycznej mantry przez każdą brytyjską partię opozycyjną. Tymczasem, historia dowodzi, że quangos wykazują się niemal przeciwpożarową odpornością w tym sensie, że każda próba ich znoszenia lub reformy rzadko kiedy stawała się rzeczywistością" ${ }^{\prime 47}$.

Co jest przyczyną owej „ognioodporności”, tj. trwałości i siły, quangos? Dlaczego tak trudno je znieść, zreformować, a przynajmniej ograniczyć koszty ich funkcjonowania? Częściowej odpowiedzi dostarcza Christopher Hood, wskazując przynajmniej cztery argumenty, dla których - niezależnie od wypowiedzi polityków - istnienie takich organizacji jest im na rękę:

- administracja rządowa potrzebuje podmiotów, od których działań może się dystansować, zwłaszcza gdy funkcjonują one we „wrażliwych sferach”,

- korzystne jest powoływanie przez permanentnie funkcjonującą administrację krótkotrwało działających organizacji dla rozwiązywania przejściowych problemów, które to organizacje mogą

\footnotetext{
45 N. RAO, op. cit., s. 62.

46 M. Garnett, P. Lynch, Exploring British Politics, New York 2012, s. 17.

47 M. Flinders, K. Dommett, K. Tonkiss, op. cit., s. 59.
} 
być później łatwo zniesione (gdy przejściowe problemy zostaną rozwiązane),

- stanowią przydatny instrument prowadzenia walki politycznej (m.in. poprzez dostarczanie stanowisk klientom politycznym na zasadzie patronażu),

- ich istnienie pozwala politykom na budowanie narracji politycznych i kreowania wizerunku (podczas gdy rządzący skupiają się na relacjonowaniu postępów w naprawianiu quangos, opozycja krytykuje oraz przedstawia plany ich reformy $)^{48}$.

Poza tym wskazuje się dodatkowe zalety powoływania i funkcjonowania quangos: ze względu na ich specjalizację (wąski zakres działania) dostarczają eksperckiej wiedzy na temat konkretnych problemów społecznych, zapewniają udział „czynnika społecznego" w kreowaniu polityk i realizacji usług (doskonałym przykładem jest tu instytucja „Board of Visitors”, która może być rozumiana jako "rada monitorująca” lub „rada społeczna” działająca przy każdej angielskiej i walijskiej instytucji sytemu penalnego; m.in. jej członkowie zobowiązani są przynajmniej raz w miesiącu bez zapowiedzi wizytować więzienie, a więźniowie mają prawo do kontaktu $\mathrm{z}$ radą $\mathrm{i}$ jej indywidualnymi członkami; rada regularnie sporządza raporty i może, w przypadku wykrycia nieprawidłowości, podejmować interwencje w organach nadzorujących jednostkę; od członków rady nie wymaga się posiadania jakichkolwiek kwalifikacji, za wyjątkiem spełnienia wymogu, by przynajmniej dwóch członków rady było sędziami pokoju - ma to dwa główne cele: zapewnienie, by przedstawiciele społeczeństwa monitorowali warunki panujące w więzieniach, w tym także rozpatrywanie skarg osadzonych oraz udział w orzekaniu o konsekwencjach naruszenia dyscypliny przez więźniów $\left.{ }^{49}\right)$, ułatwiają koordynację działań na linii: administracja rządowa - grupy interesu ${ }^{50}$.

Nie może zatem dziwić, że postulaty konserwatystów, w tym także hasło redukcji quangos, przejęli ich główni rywale polityczni. „Laburzyści

48 C. Hood,Spare that Quango, [w:] Big Government in Hard Times, red. C. Hood, M. Wright, Oxford 1981, s. 100-122.

49 G. Zellick, Lay Involvement in Prison Administration: The British Board of Visitors, «The University of Toronto Law Journal» 27/1977, s. 105-118.

50 Opening upQuangos, «Consultation Paper» 3/1997. 
paradoksalnie nawoływali do realizacji thatcherystowskiej wizji „wolnego społeczeństwa”, w której interwencjonizm państwowy w stosunkach społeczno-ekonomicznych i politycznych powinien ograniczać się do niezbędnego minimum. Równocześnie Partia Pracy krytykowała stosowaną przez rządy M. Thatcher i Johna Majora praktykę przekazywania kompetencji instytucji publicznych na rzecz organizacji pozarządowych, wskazując na negatywne aspekty quangokracji..., a zwłaszcza «rozkwit 'patronatów', korupcję, nepotyzm oraz 'deficyt demokracji' w polityce brytyjskiej na szczeblu lokalnym i regionalnym». W przeciwieństwie do konserwatywnej koncepcji stymulowania aktywności obywatelskiej w wymiarze indywidualnym, Labour Party postulowała instytucjonalne i finansowe wzmocnienie samorządów lokalnych oraz utworzenie regionalnych struktur administracyjnych o charakterze przedstawicielskim"51. W jednym z oficjalnych dokumentów z 1998 r. Partia Pracy „zobowiązała się do zmniejszenia liczby NDPBs i zapewnienia, że nowa NDPB zostanie utworzona tylko wtedy, gdy wykazane zostanie, że jest to najbardziej opłacalny i właściwy sposób realizacji danego zadania publicznego" 52 , a sporą popularność zdobyła krytyczna wypowiedź Tony'ego Blaira na konferencji prasowej w 1996 r. o „modelu państwa-quango, którego miejsce jest na śmietniku historii” ${ }^{53}$. Liderzy konserwatystów (Tim Loughton) nie mieli tym razem wątpliwości co do szans realizacji tych zapowiedzi, uznając je za „mydlenie oczu” elektoratowi przez polityków.

\section{RAYNERYZM W PRAKTYCE}

Choć, jak wykazano powyżej, poważne wątpliwości budzą „sukcesy” thatcherowskich rządów w ograniczaniu quangos i związanych z nimi

51 B. H. Toszek, E. Kużelewska, op. cit., s. 35.

52 White Paper: Quangos: Opening the Doors, London 1998.

53 T. BlaIr, British Political Speech Archive, Blackpool 1996 - Tony Blair (Labour), http://www.britishpoliticalspeech.org/speech-archive.htm?speech=202, dostęp 10 września 2015 r. 
praktyk patronażu, korupcji politycznej oraz „rozdętej” sfery publicznej - poza sporem jest fakt, iż prawdziwa zmiana dotknęła civil service.

Podkreśla się tu często rolę Dereka Raynera ${ }^{54}$, dyrektora zarządzającego firmy Marks \& Spencer, który od maja 1979 r. pełnił funkcję doradcy Thatcher (co ciekawe, jedynie raz w tygodniu i bez pobierania za to wynagrodzenia ${ }^{55}$ ), odpowiedzialnego m.in. za kontrolę efektywności administracji publicznej. Nie był to pierwszy kontakt Raynera z polityką, zbierał bowiem doświadczenie już wcześniej jako jeden z doradców konserwatywnego premiera Edwarda Heatha na początku lat siedemdziesiątych. Działania Raynera obnażyły liczne przykłady skandalicznego marnotrawienia środków publicznych ${ }^{56}$, a jedną z głównych jego zasług: było utworzenie tzw. „Efficiency Unit” - jednostki służącej podniesieniu efektywności administracji oraz „szukania oszczędności” w sferze publicznej. Biznesowe i nowatorskie podejście Raynera (zgodne z powtarzaną przez niego maksymą: „największymi wrogami działań rządu są: papier oraz tyrania przyzwyczajeń z przeszłości”"57) zaowocowało szeregiem pomysłów, które nie koncentrowały się tylko na reformach instytucjonalnych, ale dotyczyły także codziennego sposobu funkcjonowania urzędników - miały na celu polepszenie ich wydajności oraz ograniczenie typowych biurokratycznych obowiązków, na których wypełnianie przeznaczano wiele czasu i energii, a nie przynosiły one

54 Znaczenie osoby Raynera i jego wpływ na Thatcher pozwoliło nawet ukuć termin konkurencyjny do "thatcheryzmu”, czyli "rayneryzm" (raynerism). Tak np.: N. WARNER, Raynerism in Practise: Anatomy of a Rayner Scrutiny, «Public Administration» 62/1984, s. 7-22; G. Fry, Policy \& Management British Civil Service, London 1996.

55 The National Archives (TNA), PREM19/60, 'Records of the Prime Minister's Office: Correspondence and Papers, 1979-1997: Appointment of Sir Derek Rayner as adviser to assist departments in promoting efficiency and eliminating waste; review of quangos; part 1', Sir John Hunt to Margaret Thatcher, 7 May 1979.

56 Przykładowo, w wyniku zainicjowanej przez Raynera kontroli wykazano, że Ministerstwo Rolnictwa (Ministry of Agriculture) hodowało szczury, wykorzystywane później do badań laboratoryjnych, co kosztowało budżet kwotę w wysokości 30 funtów za szczura w sytuacji, gdy komercyjnie mógł być zakupiony za... zaledwie 2 funty. E.A. Reitan, The Thatcher Revolution: Margaret Thatcher, John Major, Tony Blair, and the Transformation of Modern Britain, 1979-2001, Oxford 2003, s. 98.

57 D.J. Savoie, op. cit., s. 99. 
realnych korzyści dla administrowanych. Jak sam powtarzał, chodziło nie tylko o formalną restrukturyzację, ale przede wszystkim „zmianę kultury służby cywilnej i jej nawyków"58.

„Rayner naciskał na odejście od „papierkowej roboty”. Postulował zniesienie dwudziestu siedmiu tysięcy najróżniejszych formularzy urzędowych oraz modyfikację czterdziestu tysięcy innych druków. Pewne oszczędności zostały dzięki temu poczynione, lecz służba cywilna narzekała, że mają one jedynie symboliczne znaczenie. Jednak najpoważniejszą zasługą Raynera było zainicjowanie procesu decentralizacji administracji. Rozpoczął od ustanowienie «centrów kosztów» (cost centers) zarządzanych przez urzędników, nad którymi przydzielono minimalny nadzór właściwym departamentom. Nowy system został tak zaprojektowany, by określać cele, mierzyć rezultaty oraz planować koszty" "59. Symboliczne znaczenie ma też anegdota, powtarzana w licznych publikacjach przez Donalda J. Savoie, jakoby Margaret Thatcher zmuszała najwyższych urzędników do studiowania literatury dotyczącej teorii wyboru publicznego ${ }^{60}$ (co obrazować ma swoistą atmosferę lat osiemdziesiątych, ducha nowego zarządzania publicznego).

Innym znakiem czasu było (na co, za Andrew Grayem i Billem Jenkinsem, zwracają uwagę Michał Kulesza i Dawid Sześciło) nowe spojrzenie na „treści podstawowych podręczników przeznaczonych dla brytyjskich studentów administracji. Podręcznik wydany w końcu lat 70. XX w. skupiał się na organizacji rządu centralnego, historii służby cywilnej, procesach decyzyjnych w administracji. Tymczasem podręcznik wydany niespełna dwie dekady później, już po «rewolucji NPM», wypełniony był analizą różnych aspektów zarządzania publicznego - zasad rynkowych, metod pomiaru efektywności sektora publicznego i sposobów zarządzania publicznego zorientowanych na odbiorcę. Całość uzupełniały ponadto liczne odniesienia do literatury ekonomicznej"'61.

58 D.J. Savoie, op. cit., s. 119.

59 E.A. Reitan, The Thatcher Revolution: Margaret Thatcher, John Major, Tony Blair, and the Transformation of Modern Britain, 1979-2001, Oxford 2003, s. 98.

60 D.J. Savoie, op. cit., s. 93.

61 M. Kulesza, D. SzeŚciŁo, op. cit., s. 70-71. 
Raynerowi, podobnie jak i innym ekspertom w otoczeniu Lady Thatcher, zależało ponadto na zreorganizowaniu służby cywilnej, czego skutkiem miało być odejście od hierarchicznej struktury i biurokratycznego modelu działania. „W 1979 roku Margaret Thatcher przedsięwzięła zwarty atak na Służbę Cywilną, który początkowo przyjął formę redukcji (wszelka rekrutacja została wstrzymana i narzucono niewielki budżet przeznaczony na sprawy kadrowe), a następnie pozbawiono służbę cywilną pewnych przywilejów. Tak długo utrzymująca się praktyka uzależnienia płac Służby od ruchów płacowych w sektorze prywatnym została zaniechana"62. Promowano wizję, zgodnie z którą pewnego dnia służba cywilna składać się będzie z niewielkiego jądra zaangażowanego w wypracowanie polityk: wspierając ministrów oraz zarządzając departamentami, podczas gdy pozostała masa kadr civil service obsługiwać będzie liczne, niezależne od siebie agencje wykonawcze, których rolą będzie dostarczanie usług ${ }^{63}$. Prowadzić do tego miała idea zastąpienia wielkich departamentów agencjami - jednostkami o dużej samodzielności.

Na szczycie nowej służby cywilnej stałaby grupa ok. 50 tys. jej członków, do których obowiązków należałby również udział w kreowaniu polityk publicznych. Natomiast pozostała grupa ludzi, w liczbie ok. 550 tys. urzędników, wykonujących zadania typowe, rutynowe - wchodziłaby w skład agencji, działających na podstawie modelu biznesowego (nieprzypadkowo obsługiwani przez nich obywatele charakteryzowany byli jako klienci - „customers”). Jednym z założeń było odseparowanie polityki (kreowania kierunków reform oraz udział w tworzeniu polityk) od „administrowania”, zarządzania i dostarczania usług. Luc Verhey akcentuje, że reforma miała na celu spowodowanie, aby ok. 95\% energii służby publicznej poświęcanej było na dostarczanie usług (service delivery), natomiast pozostałe $5 \%$ na udział w kreowaniu polityk

62 S. Horton, Zarzq̨dzanie Zasobami Ludzkimi (HRM) w Brytyjskiej Służbie Cywilnej, [w:] Rozwój kadr w administracji publicznej, red. B. KuDRYCKA, Białystok 2001, s. 88-90.

63 D.J. Savole, Breaking the Bargain: Public Servants, Ministers, and Parliament, Toronto-Buffalo-London 2003, s. 57. 
(policy making) ${ }^{64}$. „Głównym celem było rozdzielenie monolitycznej struktury civil service na wiele oddzielnych sfer działalności, z których każda byłaby zarządzana osobno - a zatem wolna od dotychczasowej hierarchii, a także bieżącej polityki. Zmiany te miały zmienić nie tylko konstrukcję, ale i naturę działania służby cywilnej"65.

Koncepcja przeniesienia licznych kompetencji do agencji, które w poważnym stopniu uniezależnione zostaną od dotychczasowego aparatu administracyjnego (ministerstw), nie była jednak zupełnie nowa. Poważnego impulsu dostarczała już treść Raportu Komisji Fultona (Fulton Committee Report on the Civil Service) z 1968 r. Postulowano w nim reformę tradycyjnych departamentów oraz usprawnienie zarządzania służbą cywilną. Środkiem do tego miał być m.in. pomysł (wzorowany na rozwiązaniach szwedzkich, choć z uwzględnieniem odmiennej brytyjskiej tradycji) wydzielenia specjalnych jednostek, które - poza departamentami - wykonywać będą szereg zadań publicznych. Jako przykłady takich ciał Raport Komisji Fultona wskazywał Urząd Lotnictwa Cywilnego (Civil Aviation Authority) i Komisję Zdrowia i Bezpieczeństwa (Health and Safety Commission) ${ }^{66}$.

\section{NASTĘPNE KROKI}

Rozwinięciem i realizacją tez Komisji Fultona stał się program „Następnych Kroków" (Improving Management in Government: The Next Steps), przygotowany w 1987 r. i ogłoszony rok później (ze względu na promowane radykalne rozwiązania konserwatyści postanowili odczekać na okres powyborczy - nieprzypadkowo zresztą, tezy raportu spotkały się z podzielonymi, a zwłaszcza mocno ograniczonym optymizmem członków civil service ${ }^{67}$; pojawiły się również podejrzenia i plotki, jakoby

64 L. Verhey, T. ZWARt, op. cit., s. 21.

65 C. Pilkington, The Civil Service in Britain Today, New York 1999, s. 73.

66 L. Verhey, T. Zwart, Agencies in European and Comparative Perspective, Antwerp-Oxford-New York 2003, s. 21.

67 A. Flynn, A. Grey, W.I. Jenkins, Taking the Next Steps: The Changing Management of Government, «Parliamentary Affairs»43.2/1990, s. 159. 
program ten stanowił wprowadzenie do procesu „hurtowej prywatyzacji całej służby cywilnej" ${ }^{68}$ ). Tłumaczono, że dotychczasowy model służby cywilnej jest nieefektywny i niepodatny na zmiany: „służba cywilna w aktualnym stanie jest przerośnięta i zbyt różnorodna, by zarządzać nią jako jednym podmiotem. Zatrudniając 600 tys. ludzi jest gigantyczną organizacją, zwłaszcza w porównaniu do spółek prywatnego sektora... Pojedyncza organizacja, która spełnia jednocześnie tak różne funkcje: począwszy od wydawania praw jazdy, ochrony rybołówstwa, łapania przemytników narkotyków i przygotowywaniu odpowiedzi interpelacje parlamentarne, jest niezdolna do wypełniania swoich funkcji w sposób wydajny" . Kiedy Margaret Thatcher odchodziła z mieszkania przy Downing Street nr 10, działały już 34 agencje, zatrudniające łącznie około 80 tys. pracowników ${ }^{70}$.

Idea tworzenia specjalistycznych agencji wykonawczych odpowiadała idei „dezagregacji”, tj. rozbijania molochów administracyjnych (gigantycznych struktur administracyjnych, np. ministerstw, departamentów czy urzędów centralnych zatrudniających kilkutysięczne rzesze pracowników, operujące rozdętymi budżetami z przypisanym szerokim zakresem działania) na jednostki mniejsze, skromniej finansowane i skoncentrowane na wykonywaniu konkretnych wąsko określonych zadań. Rozwiązaniu temu towarzyszyć miały liczne zalety: instytucje poddane dezagregacji uchodzą za bardziej elastyczne, wyspecjalizowane (a zatem bliższe świadczeniobiorcom oraz innym podmiotom działającym w danej sferze) oraz innowacyjne. Udowodniono także, że warunki w nich panujące działają znacznie bardziej mobilizująco na zatrudnionych w nich pracowników, a ryzyko wystąpienia konfliktów i napięć jest tu mniejsze ${ }^{71}$.

Choć agencje wykonawcze trudno uznać - w odróżnieniu od departamentów - za element administracji rządowej, stanowią one jej

68 C. Pilkington, op. cit., s. 76.

${ }^{69}$ K. Jenkins, K. Caines, A. JaCkson, Improving Management in Government: The Next Steps., London 1988, s. 4-5.

70 E.A. Reitan, op. cit., s. 98.

${ }^{71}$ D. Osborne, T. GAebler, Rzadzić inaczej. Jak duch przedsiębiorczości przenika administrację publiczną, Poznań 2005, s. 343-345. 
funkcjonalne przedłużenie: wykonują jej zadania, są odpowiedzialne za realizację polityk publicznych artykułowanych przez regulacje prawne i finansowane przez środki budżetowe ${ }^{72}$. „Agencje, które zatrudniały prawie 400000 osób, nie są formalnie urzędami administracji jeżeli występują w sferze prawa administracyjnego działają w imieniu danego ministerstwa... tworząc agencje, starano się maksymalnie wyzyskać w ich ramach instrumenty rynkowe i quasi-rynkowe (np. umowa z właściwą agencją w sprawie czasu, w jakim wydawane są paszporty). Z tego powodu nie może dziwić, że formę tę nadano wielu dotychczasowym jednostkom usługowym, jak drukarni rządowej (Her Majesty's Stationery Office)"73. Akcentowano szereg zalet promowanego rozwiązania: „funkcjonowanie wyodrębnionych agencji wykonawczych nie wymaga doglądania przez ministrów ich codziennego działania oraz zwalnia od odpowiedzialności za ich aktywność; praca wykonywana przez konkretną jednostkę jest znacznie bardziej efektywna niż departament, którego zakres działania jest znacznie szerszy; pozwala powierzyć zarządzanie tymi jednostkami osobom spoza administracji rządowej oraz zapewnić, że ich działanie nie będzie podlegać wpływom politycznej walki partyjnej"74.

Jak podkreśla jednak Matthew Flinders, równie silnej motywacji w tworzeniu agencji dostarczały argumenty natury politycznej: chodziło przede wszystkim o przekonanie opinii publicznej o realizowaniu polityki „odbiurokratyzowania” administracji. Tworzenie agencji, które przejmowały część zadań dotychczasowych ministerstw pozwalało nie tyle znieść, co „ukryć” biurokrację i wykazać w ten sposób sukcesy w procesie „kurczenia się państwa”. Działała tu zatem podobna motywacja, jak w przypadku dotychczasowej praktyki powoływania quangos. Co więcej, działanie agencji (spośród których liczne uzyskały kompetencję w zakresie władztwa regulacyjnego kosztem dotychczasowych ministerstw) wpisywało się w lansowany wizerunek konserwatystów

72 A.M. Bertell, Governing the Quango: An Auditing and Cheating Model of Quasi-Governmental Authorities, "Journal of Public Administration Research and Theory» 16/2005, s. 241-242.

73 H. Izdebski, M. Kulesza, op. cit., s. 172.

74 L. Pliatzky, Report on Non-Departmental Bodies, London 1980, s. 557. 
jako antyetatystów i zwolenników państwa minimalnego. Mimo, że konieczność regulacji w coraz to nowych dziedzinach rosła, rządzący mogli w końcu powiedzieć: rząd nie wkracza w relacje rynkowe, a nawet wycofuje się z dotychczasowych sfer działania. Fakt, że porządkowaniem tych sfer zajęły się agencje - nie świadczy wcale o rosnącej roli państwa, cieszą się one dużą niezależnością, a zatem ich funkcjonowanie nie może być traktowane jako ingerencja w mechanizmy gospodarki wolnorynkowej ${ }^{75}$. Powołanie agencji było po prostu wygodne: zwalniało polityków z licznych trosk, pozwalało utrzymać regulację (niezależną od rządu) w wielu dziedzinach życia, a uczestnikom rynku i samym konsumentom dawało poczucie, że rząd nie ingeruje w ich interesy, lecz jest jednocześnie „ktoś”, kto wciąż czuwa nad ich bezpieczeństwem.

W końcu, kierując się wnioskami teorii „kształtowania urzędu” (bureau-shaping) Patricka Dunleavy’ego, założenia reformy miały pozostawać w zgodzie z interesami samych urzędników. Zgodnie z tym spojrzeniem, źródeł motywacji oraz zadowolenia kadr administracji publicznej nie można upatrywać wyłącznie w ich zarobkach, ale tym, co wpływa na ich komfort pracy (a znajduje przełożenie realne w zaangażowaniu w wykonywaną pracę oraz wynikach) jest struktura urzędu ${ }^{76}$. „Urzędnicy (z uwagi na ich status) wolą być zatrudniani w małych urzędach o niewielkim zakresie zadań i odpowiedzialności, aniżeli pracować w dużych aparatach administracyjnych, które generują wiele konfliktów, problemów i generalnie ryzyka związanego z odpowiedzialnością. Urzędnicy wyznający teorię bureau-shaping są zwolennikami tworzenia «agencji administracyjnych», nie zaś powiększania zakresów obowiązków i struktur pojedynczych urzędów... Teoria opracowana przez P. Dunleavy'ego dotyczy wysokich urzędników publicznych,

75 M.V. Flinders, Quangos: Why Do Governments Love Them?, [w:] Quangos. Accountability and Reform. The Politics of Quasi-Government, red. M.V. FLInders, M.J. SMith, London 1999, s. 33 i n.

76 P. Dunleavy, Democracy and Public Choice, Routledge, London-New York 1991; wpływ koncepcji Dunleavy’ego na reformę Next Steps oraz jej efekty (z uwzględnieniem fragmentów wywiadów z urzędnikami) omówiony w: D. MARsh, M.J. SMith, D. Richards, Bureaucrats, Politicians and Reform in Whitehall: Analysing the Bureau-Shaping Model, «British Journal of Political Science» 3/2000, s. 461-482. 
których ambicją jest praca polegająca na wykonywaniu ważnych zadań z zakresu polityki publicznej, nie zaś technicznych działań związanych z codziennym funkcjonowaniem biura/urzędu. Teoria ta powstała przy okazji analizowania reform administracji centralnej w Wielkiej Brytanii w latach 80. XX wieku. Wówczas to Margaret Thatcher dążyła do zmniejszenia rozmiarów biurokracji brytyjskiej poprzez takie działania jak prywatyzacja, outsourcing, zmniejszenie budżetów jednostek centralnych itd. W przeciwieństwie do opisanej wyżej maksymalizacji finansowej, racjonalni biurokraci, których urzędy podlegały reorganizacji, byli skłonni zaakceptować zmiany tylko dlatego, że woleli pracować w mniejszych, bardziej elitarnych zespołach i być ulokowani blisko politycznych centrów decyzyjnych" "77. Nie sposób też nie dostrzec politycznego wymiaru koncepcji Następnych Kroków. Jej realizacja pozwoliła nie tylko pozbyć się wielu agencji publicznych utworzonych po wojnie przez rządy labourzystowskie, ale - zasłaniając się wymogami reformy, potrzebą ich reorganizacji oraz zarzutami rzekomej niskiej efektywności dotychczas funkcjonujących instytucji - powołać w to miejsce nowe agencje wykonawcze obsadzone już przez sympatyków Partii Konserwatywnej ${ }^{78}$.

Przykładowe agencje wykonawcze to: Agencja Paszportowa (United Kingdom Passport Agency), Inspektorat ds. Pojazdów (Vehicle Inspectorate), Służba Więzienna Jej Królewskiej Mości (Hej Majesty Prison Service), czy Agencja Kontroli Leków (Medicines Control Agency). Rezultatem reformy „Next Steps” było powołanie ponad stu agencji, które konsekwentnie „przejmowały” członków służby cywilnej (w 1993 r. funkcjonowało już 89 agencji które angażowały 260 tys. członków służby cywilnej, co stanowiło 49\% całości jej kadr"; w 1999 r. miały być już dokładnie 134 agencje, które dawały pracę około 75\% wszystkich

77 P.J. Suwaj, A. Kudrycka, G. Peters, Nauka administracji, Warszawa 2009, s. $172-173$.

78 R.R. NeIld, Public Corruption: The Dark Side of Social Evolution, London 2002, s. 181.

79 P. Greer, Transforming Central Government: the Next Steps, Buckingham 1994, s. VII. 
członków służby cywilnej) ${ }^{80}$. Powiedziano, że dysponowały one na ogół ${ }^{81}$ dość szerokim zakresem samodzielności - departamenty określały ich budżet oraz generalny kierunek ich polityki, wyznaczały efekty, które miały być osiągane, a także monitorowały postępy w ich realizacji. Szczegółowo relację na linii departament - agencja normowała „umowa ramowa" (framework agreement), quasi-kontrakt, zawierany na rok oraz publikowany. Wywiązywanie się z zobowiązań podlegało weryfikacji: agencje oceniane były na podstawie ilości i jakości dostarczanych usług oraz stopnia zaspokojenia potrzeb odbiorców.

Przejawem owej samodzielności (niektórzy anglosascy autorzy mówią nawet o „autonomii” lub „niezależności”) był fakt, iż - w ramach przyznanego rocznego budżetu - zdolne były do decydowania o metodach wydatkowania przyznanych środków, w tym zawierania kontraktów z usługobiorcami z sektora prywatnego. Początkowo na czele agencji stali szefowie wywodzący się ze służby cywilnej, z czasem (od połowy lat dziewięćdziesiątych) w otwartych konkursach zwyciężali też menadżerowie doświadczeni w zarządzaniu firmami w sektorze prywatnym (przykładem jest biznesmen Derek Lewis, który zdobywał doświadczenie w branży samochodowej, a w 1992 r. objął stanowisko Dyrektora Generalnego Służby Więziennej Jej Królewskiej Mości). Sytuacja ta powodowała niezadowolenie członków civil service nie tylko z powodu rywalizacji, którą zmuszeni byli podejmować w ubieganiu się o najwyższe stanowiska, ale i ze względu na fakt, że zarządzający potężnymi agencjami menedżerowie uzyskiwali wynagrodzenia niewyobrażalne dla najstarszych rangą urzędników civil service ${ }^{82}$.

80 L. Verhey, T. ZWART, op. cit., s. 27.

${ }^{81}$ Pamiętać trzeba, że instytucja agencji nie doczekała się jednolitego wzoru, ustandaryzowanego schematu organizacyjnego i jednolitego status prawnego. Liczne agencje powoływane były do tworzenia odmiennych zadań, w rezultacie różna była ich wielkość, struktura i pozycja. Były wśród nich agencje wielkie (zatrudniające kilkadziesiąt tysięcy ludzi - np. Agencja ds. Zasiłków, „Benefits Agency”) oraz mikroskopijne, zatrudniające tylko kilkudziesięciu pracowników.

${ }^{82}$ Przykładowo: wspomniany wyżej Derek Lewis otrzymywał wynagrodzenie w wysokości 133 tys. funtów, podczas gdy członkowie służby cywilnej zajmujący porównywalne rangą stanowiska mogli liczyć zaledwie na płacę w wysokości około 73 tys. funtów. C. Pilkington, op. cit., s. 82. 
Konsekwencją jest stan obecny, czyli sytuacja, w której „służby publiczne Wielkiej Brytanii i Irlandii Północnej zatrudniają ok. 560 tys. pracowników. Pracują oni w 20 głównych ministerstwach i w przeszło 100 agencjach wykonawczych. Na wyższych szczeblach zatrudniani są częściej dyrektorzy generalni, na niższych - specjaliści, mający określone umiejętności zawodowe i techniczne" ${ }^{\text {"33 }}$. Teza o wzroście wydajności członków civil service jest, generalnie rzecz biorąc, powszechnie podzielana. „Poprawa efektywności działania administracji została osiągnięta dzięki wprowadzeniu instytucji agencji wykonawczych, których szefowie, podobnie jak menedżerowie sektora rynkowego, mieli dużą swobodę w doborze metod realizacji zadań i prowadzeniu polityki kadrowej. Agencje wykonawcze tworzone były celem decentralizacji zarządzania, odseparowania polityki i administracji, oraz ograniczenia hierarchiczności administracji. Miały one precyzyjnie zdefiniowane kompetencje i zadania, były rozliczane z osiąganych wyników na podstawie rocznych, obowiązkowo publikowanych raportów i podlegały nadzorowi organów politycznych, tj. odpowiednich ministrów. Cechą reform brytyjskich było powstanie quasi-rynków w ochronie zdrowia, opiece społecznej, szkolnictwie (na każdym poziomie) i więziennictwie. Ich rozwój skutkował wprowadzeniem zmian w kulturze organizacji sektora publicznego, m.in. funkcje kierownicze były definiowane na wzór zadań menedżerów przedsiębiorstw prywatnych oraz wprowadzono elementy planowania i zarządzania strategicznego. W Wielkiej Brytanii, podobnie jak w Stanach Zjednoczonych, przywiązywano dużą wagę do wdrażania systemów kontroli jakości. Powszechne jest tam stosowanie norm ISO w administracji publicznej, a certyfikowane jest blisko 90\% usług samorządów lokalnych" ${ }^{" 4}$.

\section{OdCHUdZONE PAŃSTWO CZY NOWA BIUROKRACJA?}

Co zostało z ambitnych deklaracji odbiurokratyzowania kraju i deregulacji gospodarki? , Rezultatem tej polityki było wzmocnienie rządu 
centralnego i, paradoksalnie, stworzenie nowych biurokracji, którą rzekomo Margaret Thatcher chciała ograniczyć" 85 . Jeszcze dalej idzie John Gray, w latach osiemdziesiątych gorący zwolennik thatcheryzmu, który nie zostawia dziś suchej nitki na dawnym idolu: „Thatcher chciała przebudować kraj na fundamentach takich tradycyjnych wartości jak poczucie obowiązku i rodzina. Tymczasem, niszcząc etos służby publicznej i głosząc, że coś takiego jak społeczeństwo nie istnieje, przyczyniła się do powstania społeczeństwa, w którym najwyższym ideałem jest samorealizacja. Postthatcherowska Wielka Brytania ma bezpruderyjny stosunek do seksu, zadłuża się na potęgę i nie jest zainteresowana «tradycyjnymi wartościami». Nadal jest jednak tworem Thatcher, toteż odwracając się do niej plecami, a jednocześnie stając po stronie tych wartości, które ona niechcący wykreowała, Cameron sprawił, że Nowa Partia Pracy stała się niepotrzebna" 86 . Co więcej, uczeń Berlina i Oakeshotta konstatuje, że „postrzegana była jako przeciwniczka państwa opiekuńczego, lecz pozostawiła je jeszcze bardziej rozbudowane niż przed objęciem władzy"87.

Może zatem - zamiast rozważać silnie ideologiczne i nieco abstrakcyjne zagadnienie modelu państwa oraz jej zasług dla realizacji w praktyce wartości filozofii publicznej neoliberalizmu - warto podkreślić rolę „Żelaznej Damy” w transformacji brytyjskiej służby cywilnej. Może lepiej nie tracić czasu na rozliczanie konserwatystów z efektów „thatcherowskiej rewolucji" i jałowe rozważania, czy radykalne zapowiedzi wyborcze zostały urzeczywistnione, a skupić się na zagadnieniu znacznie bardziej przyziemnym i mniej politycznym, jakim jest modyfikacja zarządzania publicznego? Okaże się wówczas, że rację ma Colin Pilkington, gdy podkreśla: „tym, co pozostało po odejściu Margaret Thatcher - z tych wszystkich jej zapewnień o „wycofaniu się państwa” - jest prawdziwa transformacja służby cywilnej, która przestała być wreszcie jałową biurokracją. Program «Następnych kroków» i przekazanie służby

85 L. RajCA, Reformy samorzadu..., s. 58.

86 J. Gray, Partia Pracy i mity thatcheryzmu ..., s. 34.

87 J. Gray, Margaret Thatcher's Unintended Legacies, «New Republic», http:// www.newrepublic.com/article/114223/margaret-thatcher-reviewed-john-gray, dostęp 3 września 2015 r. 
cywilnej do sieci agencji naprawdę zmieniły jej naturę, strukturę, a także sposób działania"88.

\section{MięDZY BIURokracją, A QUANGOKRACJĄ. KilKa SŁóW O REFORMIE SŁUŻBy CYWILnej ZA CZasów Margaret Thatcher}

\section{Streszczenie}

Artykuł przedstawia wybrane reformy Służby Cywilnej Jej Królewskiej Mości w okresie premierostwa Margaret Thatcher (1979-1990).

Przez ostatnie lata, oceniając rządy Thatcher, mówiono głównie na temat polityki zagranicznej „Żelaznej Damy”, jej intelektualnych inspiracjach (neoliberalizm lub „nowa prawica”), zdolnościach przywódczych, efektach prywatyzacji oraz deregulacji, a także kampanii wymierzonej w związki zawodowe. Z drugiej strony, niektóre z decyzji podejmowane w okresie rządów Partii Konserwatywnej (pod przywództwem Thatcher i Johna Majora) pozostają wciąż przedmiotem kontrowersji i sporów, między innymi kwestie: poll-tax, reformy samorządu terytorialnego i właśnie służby cywilnej.

Zgodnie z dominującym poglądem, działania podjęte przez konserwatystów na tym polu mogą być postrzegane jako „rewolucja w służbie cywilnej".

Thatcher była przekonana, że służbę cywilną cechuje nadmiar etatów i nieefektywność. Konserwatyści krytykowali takie zjawiska, jak patronaż, biurokracja oraz przerost administracji. Wprowadzono zatem poważne zmiany, m.in.: Efficiency Unit kierowany przez Lorda Raynera, liczba członków civil sercice zmniejszyła się o 171 tys., program „Następnych Kroków” oraz promowano „nową kulturę urzędniczą” (np. postrzeganie obywateli jako konsumentów, decentralizacja i dezagregacja, zmniejszenie „papierkowej roboty”, rywalizacja w sektorze publicznym). 
Between Bureaucracy and Quangocracy: A Few Words on the Reform of the Civil Service under the Thatcher Government

\section{Summary}

This article discusses selected components of the reform of Her Majesty's Civil Service conducted by the Thatcher ministries (1979-1990). In recent years assessments of the Thatcher government have tended to focus chiefly on the Iron Lady's foreign policy, her intellectual inspirations (neoliberalism or the New Right), her leadership qualities, the effects of privatisation and deregulation, and her anti-trade union campaign. Yet on the other hand some of the decisions made by the Conservative cabinets led by Margaret Thatcher and John Major are still giving rise to disputes and controversy, and these issues include poll tax, local government reform, and the reform of the civil service. The prevailing view is that the measures the Conservatives took on this last issue may be regarded as "a revolution in the Civil Service." Thatcher was convinced that the civil service was overstaffed and inefficient. The Conservatives were critical of phenomena like patronage, bureaucracy, and a surfeit of administrative staff. Far-reaching changes were made, with the introduction of Lord Rayner's Efficiency Unit, which reduced staff numbers by 171 thousand; the Next Steps Initiative; a "new civil service culture" which perceived British citizens as consumers; decentralisation and disaggregation; cuts in the paperwork; and competitiveness in the public sector.

Słowa kluczowe: administracja publiczna; służba cywilna; biurokracja; konserwatywna rewolucja; taczeryzm.

Keywords: public administration, the Civil Service, bureaucracy, the Conservative revolution, Thatcherism.

\section{Literatura}

Bertelli M., Governing the Quango: An Auditing and Cheating Model of Quasi-Governmental Authorities, «Journal of Public Administration Research and Theory» $16 / 2005$ 
Butcher T., The Civil Service in the 1990s: The Revolution Rolls On, «Talking Politics» 3/1995

Deviatnikovaité I., Bakaveckas A., Independent Regulatory Agencies: Possibilities to Identify the Pecularities of their Activity and their Position in the System of Lithuanian Public Administration Bodies, «Socialinių mokslu studijos» 3/2009

DŁugosz D., Kadry w administracji publicznej, [w:] Administracja publiczna, red. J, HAusner, Warszawa 2005

Dunleavy P., Democracy and Public Choice, Routledge, London-New York 1991

Flinders M.V., Quangos: Why Do Governments Love Them?, [w:] Quangos. Accountability and Reform. The Politics of Quasi-Government, red. M.V. Flinders, M.J. Smith, London 1999

Flinders M., Dommett K., Tonkiss K., Bonfires and Barbecues: Coalition Governance and the Politics of Quango Reform, «Contemporary British History» 28/2014

Flynn A., Grey A., Jenkins W.I., Taking the Next Steps: The Changing Management of Government, «Parliamentary Affairs» 43.2/1990

Fry G., Policy \& Management British Civil Service, London 1996

Garnett M., Lynch P., Exploring British Politics, New York 2012

Gray J., Partia Pracy i mity thatcheryzmu, «Dziennik» z 5 listopada 2007 r.

Greer P., Transforming Central Government: the Next Steps, Buckingham 1994

Greve C., Flinders M., van Thiel S., Quangos - What's in a name? Defining Quangos from a Comparative Perspective, "Governance»12.2/1999

Hausner J., Od idealnej biurokracji do zarzadzania publicznego, [w:] Studia z zakresu zarządzania publicznego, II, red. J. Hausner, M. KuKIEŁKA, Kraków 2002

Heywood J., Kerslake B., Margaret Thatcher: our kindly boss, by Britain's top civil servants, «The Telegraph», z 15 kwietnia $2013 \mathrm{r}$.

Holland P., Quango, Quango, Quango: the Full Dossier on Patronage in Britain, London 1979

Hood C., Spare that Quango, [w:] Big Government in Hard Times, red. C. Hood, M. WRIGHT, Oxford 1981

Horton S., Zarządzanie Zasobami Ludzkimi (HRM) w Brytyjskiej Służbie Cywilnej, [w:] Rozwój kadr w administracji publicznej, red. B. KudRYCKA, Białystok 2001

Izdebski H., Bosiacki A., Nelicki A., Zachariasz I., Nowe zarzadzanie publiczne i public governance $w$ Polsce i w Europie, Warszawa 2010 
Izdebski H., Kulesza M., Administracja publiczna. Zagadnienia ogólne, Warszawa 2004

JaWORSKa-DęBSKa B., Etos służby publicznej i jego oblicza, [w:] Służba publiczna. Stan obecny, wyzwania i oczekiwania, red. S. PŁAżek, M. SтеC, «Lex» 2013

Jenkins K., Caines K., Jackson A., Improving Management in Government: The Next Steps., London 1988

Jeżowski P. [red.], Zarządzanie w sektorze publicznym - rozwój zrównoważony - metody wyceny, Warszawa 2002

KJaer A. M., Governance ant the Urban Bureaucracy, [w:] Theories of Urban Politics, red. red. J. S. Davies, D. Imbroscio, London 2009

Kozuń-CieśLAK G., Teoretyczne koncepcje decentralizacji i delegowania kompetencji we wspótczesnych nurtach ekonomii, «Samorząd terytorialny» 9/2011 Kożuch B., Zarzadzanie publiczne. W teorii i praktyce polskich organizacji, Warszawa 2004

Kulesza M., SześciŁo D., Polityka administracyjna i zarządzanie publiczne, Warszawa 2013

Ledzion B., Olejniczak K., Pander W., Ewaluacja trafności zakresu interwencji Działania 5.1 Programu Operacyjnego Kapitał Ludzki, www.efs. kprm.gov.pl

Lee H., Regaining Political Control Over the British Quango State: The Public Bodies Reform, «Journal of Public Policy» 1/2014

Mayes D.G., Mustaffa Z., The rise of unelected. The UK health system and the rise and fall of arm's length bodies, [w:] The Changing Welfare State in Europe: The Implications for Democracy, red. D.G. MaYes, A. MichalsKi, Cheltenham 2013

Mazur S., Historia administracji publicznej, [w:] Administracja publiczna, red. J. HAUSNER, Warszawa 2005

Musialik G., Musialik R., Związek sektora publicznego i rynkowego w koncepcji New Public Management, «Studia Ekonomiczne Zeszyty Naukowe Uniwersytetu Ekonomicznego w Katowicach» 156/2013

NeIld R.R., Public Corruption: The Dark Side of Social Evolution, London 2002 Osborne D., Gaebler T., Rządzić inaczej. Jak duch przedsiębiorczości przenika administrację publiczną, Poznań 2005

Peters G., Pierre J., The Sage Handbook of Public Administration, London 2012

Pilikington C., The Civil Service in Britain Today, New York 1999 
RADZIK K., Od Thatcher do Browna: polityka rzadów brytyjskich wobec samorządu terytorialnego (1979-2010), «Zarządzanie Publiczne»13.1/2011

Pliatzky L., Report on Non-Departmental Bodies, London 1980

Reitan E.A., The Thatcher Revolution: Margaret Thatcher, John Major, Tony Blair, and the Transformation of Modern Britain, 1979-2001, Oxford 2003

Prestruus R., Mrs. Thatcher stalks the quango: a note on Patronage and Justice in Britain, «Public Administration Review»3/1981

RajCA L., Przywództwo polityczne w zachodnioeuropejski samorzadzie lokalnym, «Studia Regionalne i Lokalne»34.4/2008

RAJCA L., Reformy samorzadu lokalnego w Anglii, «Samorząd terytorialny» $12 / 2007$

Rao N., Reviving Local Democracy: New Labour, New Politics?, Bristol 2000

Savore D.J, Breaking the Bargain: Public Servants, Ministers, and Parliament, Toronto-Buffalo-London 2003

SAvore D. J., Thatcher, Reagan, and Mulroney: In Search of a New Bureaucracy, University of Pittsburgh Press, Pittsburg 1994

Smith P., Lessons from the British Poll Tax Disaster, "National Tax Journal», $4 / 1991$

Smith M.J., Richards D., Bureaucrats, Politicians and Reform in Whitehall: Analysing the Bureau-Shaping Model, «British Journal of Political Science» $3 / 2000$

Stewart-David D., ŚLIwa M., Jak efektywnie wykorzystać czas pracowników?, [w:] Rozwój kadr w administracji publicznej, red. B. KudRYCKA, Białystok 2001

Sтотт T., Quangos: are they unloved and misunderstood?, [w:] Debates in British Politics Today, red. L.J. Robins, B. Jones, Manchester 2000

Supernat J., Administracja publiczna w świetle koncepcji New Public Management, [w:] Jednostka, państwo, administracja - nowy wymiar, red. E. URA, Rzeszów 2004

Sunaj P.J., Kudrycka B., Peters G., Nauka administracji, Warszawa 2009

SyAL R., Pro-Margaret Thatcher article by two senior civil servants angers MPs, «The Guardian» z 18 kwietnia 2013 r.

Toszek B., Kużelewska E., Od wizji do rzeczywistości. Dziesięć lat dewolucji $w$ Walii, Warszawa 2011

Turnbull O., Bringing Down the House: The Crisis in Britain's Regional Theatres, Bristol 2008

Warner N., Raynerism in Practise: Anatomy of a Rayner Scrutiny, «Public Administration» 62/1984 
WRIGHT O., MPs attack top civil servants over Thatcher tribute, «The Independent» Z 18 kwietnia 2013 r.

Verhey L., Zwart T., Agencies in European and Comparative Perspective, Antwerp-Oxford-New York 2003

Zellick G., Lay Involvement in Prison Administration: The British Board of Visitors, «The University of Toronto Law Journal» 27/1977. 